\title{
PENGEMBANGAN SOFT SKILLS DAN RELEVANSINYA TERHADAP PEMBENTUKAN AKHLAK MAHASISWA: PERSPEKTIF HADIS
}

\author{
Munawarah \& Raudah Abshari \\ Sekolah Tinggi Agama Islam Rasyidiyah Khalidiyah (STAI RAKHA) \\ Amuntai \\ munawarah.pilca@gmail.com \& raudahabshar01@gmail.com
}

\begin{abstract}
A person's success is not determined solely by the knowledge and technical abilities (hard skills). But rather by the ability to manage themselves and others (soft skills) relating to factors of emotional intelligence (EQ). Because soft skills is critical given in the educational process. Inability to provide soft skills training will only result in graduates who are just good at memorizing lessons and get a little bit of skill when already in employment. Currently we are in the middle of the vortex hegomonia media, science and technology revolution. Not only is able to bring the ease and comfort of living for humans, but also invite problems and concerns. Progress in science and technology can reduce the humanitarian values or dehumanization. In the reality on the ground, moral development efforts through a variety of educational institutions and various methods continue to be developed. It shows that morality does need to be nurtured. Based on the hadith "Behold, I am sent by God to enhance budipekerti nobility" (HR. Ahmad). This type of research is qualitative research methods literature, namely data collection is done through the places of storage of research results. The data collection technique using the method of documentation, namely reference books that can be justified. Examination of the validity of data tend to use triangulation techniques theory. In this research using descriptive method with content analysis techniques, which draw a conclusion through the efforts of finding the characteristics of the message and be conducted objectively and systematically.
\end{abstract}

Keywords: Soft Skills, Moral, Students.

\begin{abstract}
ABSTRAK
Kesuksesan seseorang semata-mata tidak ditentukan oleh pengetahuan dan kemampuan teknis (hard skills). Tetapi lebih oleh kemampuan mengelola diri dan orang lain (soft skills) yang berhubungan dengan faktor kecerdasan emosional (EQ). Karena soft skills sangat penting diberikan dalam proses pendidikan. Ketidak mampuan memberikan pendidikan soft skills hanya akan mengakibatkan lulusan yang hanya pandai menghafal pelajaran dan mendapatkan sedikit keterampilan ketika sudah di lapangan kerja. Saat ini kita berada di tengah pusaran hegomonia media, revolusi ilmu pengetahuan dan teknologi. Tidak hanya mampu menghadirkan
\end{abstract}


kemudahan dan kenyamanan hidup bagi manusia, tetapi juga mengundang persoalan dan kekhawatiran. Kemajuan iptek dapat mengurangi nilai-nilai kemanusian atau dehumanisasi. Pada kenyataan di lapangan, usahausaha pembinaan akhlak melalui berbagai lembaga pendidikan dan berbagai macam metode terus dikembangkan. Ini menunjukkan bahwa akhlak memang perlu dibina. Berdasarkan hadis "Bahwasanya Aku diutus Allah untuk menyempurnakan keluhuran budipekerti" (HR. Ahmad). Jenis penelitian ini adalah kualitatif dengan menggunakan metode penelitian kepustakaan, yaitu pengumpulan datanya dilakukan melalui tempat-tempat penyimpanan hasil penelitian. Teknik pengumpulan data menggunakan metode dokumentasi, yaitu buku-buku referensi yang dapat dipertanggung jawabkan. Pemeriksaan keabsahan data cenderung menggunakan teknik triangulasi teori. Dalam penelitian ini menggunakan metode deskriptif dengan teknik analisis isi, yaitu menarik kesimpulan melalui usaha menemukan karakteristik pesan dan dilakukan secara objektif dan sistematis. Diharapkan ke depannya perguruan tinggi dapat menghasilkan output yang berkualitas dan kompetitif serta memberikan perubahan lebih baik dengan uswatun hasanah terhadap lingkungan sekitar.

Kata Kunci: Soft Skills, Akhlak, Mahasiswa.

\section{Pendahuluan}

Perkembangan zaman yang semakin pesat menuntut adanya peningkatan mutu sumber daya manusia yang berkualitas. Peningkatan sumber daya manusia tidak lepas dari dunia pendidikan. Untuk itu, pendidikan memegang peranan penting dalam meningkatan sumber daya manusia yang bermutu. Melalui pendidikan akan membentuk manusia yang terampil, kreatif, bermoral dan bermartabat tinggi, mempunyai kepekaan terhadap lingkungan dan mampu menghadapi tantangan di masa yang akan datang.

Pendidikan harus mampu menghasilkan sumber daya manusia yang tidak hanya terampil dan cerdas, namun juga bermoral. Akibat yang bisa dirasakan dari sumber daya manusia yang bermoral adalah perilaku sopan, disiplin, keteguhan hati, kemampuan kerja sama, serta membantu orang lain, yang di kenal dengan istilah soft skill. Akan tetapi faktanya soft skill yang dimiliki oleh setiap orang tidaklah sama.

Sejatinya Pendidikan dianggap sebagai salah satu cara dalam menciptakan iklim kemajuan dalam segala bidang. Namun demikian, banyaknya lembaga bukanlah jaminan suatu bangsa dapat menunjukkan 
kemajuan di setiap zamannya. Hal ini sangat dipengaruhi bagaimana pengelolaan lembaga itu sendiri.

Salah satu lembaga yang memiliki peran penting dalam pengembangan soft skill adalah perguruan tinggi. Usaha meningkatkan kualitas sumber daya manusia menjadi tantangan bagi perguruan tinggi. Idealnya pembelajaran di perguruan tinggi mengembangkan hard skills dan soft skills yang dimiliki oleh setiap mahasiswa. Namun kenyataan selama ini, perkuliahan yang terjadi terkadang masih hanya menguatkan hard skills saja. Hard skills yang dimaksud disini berkaitan dengan penguasaan materi perkuliahan (teori), sedangkan soft skills lebih kearah penguat hard skills. Menurut Wagner (2008) yang termasuk soft skills salah satunya berupa kemampuan berpikir kritis dan pemecahan masalah. Kemampuan berpikir kritis tidak dapat berkembang seiring dengan perkembangan jasmani tiap individu. Kemampuan ini berkaitan dengan kemampuan mengidentifikasi, menganalisis, dan memecahkan masalah secara kreatif dan berpikir logis sehingga menghasilkan pertimbangan dan keputusan yang tepat.

Kemampuan berpikir kritis setiap individu berbeda-beda, tergantung pada latihan yang sering dilakukan untuk mengembangkan berpikir kritis. Keantusiasan mahasiswa dalam menjawab pertanyaan yang diajukan dosen masih terbatas secara teori belum menunjukkan pengembangan yang sesuai dengan potensi serta kemampuan mereka. Selain itu, terdapat beberapa mahasiswa yang masih sulit dalam bekerja secara berkelompok, berkomunikasi, memecahkan masalah ketika diajukan contoh suatu permasalahan nyata, serta belum bisa mengambil keputusan sebagai solusi yang tepat dari suatu permasalahan.

Selama ini, mahasiswa belajar hanya terfokus pada materi dan informasi yang disajikan oleh dosen, tanpa mengetahui bagaimana realita yang terjadi di lapangan. Pembelajaran di perguruan tinggi seharusnya lebih menitikberatkan pada pemahaman materi yang diwujudkan dengan mengaplikasikan materi sesuai dengan lingkungan kerja yang akan ditemuinya.

Soft skills merupakan kompetensi bersifat non teknis yang menunjuk pada karakteristik kepribadian, nampak pada perilaku seseorang baik saat berinteraksi dalam situasi sosial, kemampuan berbahasa, kebiasaan diri, ataupun sifat-sifat penting untuk mendukung perilaku optimis. Maka, Dengan adanya pengembangan soft skill diharapakan mahasiswa memiliki motivasi yang tinggi dalam merealisasikan tri dharma perguruan tinggi. 


\section{Urgensi Pengembangan Soft Skills}

Dalam berbagai referensi ditemukan beragam definisi tentang soft skills, diantaranya LaFrance menyatakan bahwa:

"Soft skills is personal and interpersonal behaviour that develop and maximize human performance (e.g. confidence, flexibility, honesty, and integrity)" "(perilaku personal dan interpersonal yang mengembangkan dan memaksimalkan kinerja seseorang terkait kepercayaan diri, fleksibilitas, kejujuran dan integritas diri)".

Senada dengan definisi di atas, Abdullah Aly mengutip pendapat Elfindri pada peneletiannya, mendefinisikan soft skills sebagai keterampilan dan kecakapan hidup, baik untuk diri sendiri, berkelompok, atau bermasyarakat, serta dengan Sang Pencipta. Selain itu Ilah sailah juga berpendapat bahwa:

soft skills adalah "keterampilan seseorang dalam berhubungan dengan orang lain (inter-personal skills) dan keterampilan dalam mengatur dirinya sendiri (intra-personal skills) yang mampu mengembangkan secara maksimal unjuk kerja (performans) seseorang".

Jenis-jenis Soft Skills dan Bentuknya

Gambar 1

\begin{tabular}{|l|l|}
\hline \multicolumn{1}{|c|}{ Jenis Soft Skills } & \multicolumn{1}{|c|}{ Bentuknya } \\
\hline Personal & Manajemen waktu \\
& Manajemen stress \\
& Manajemen perubahan \\
& Karakter transformasi \\
Berpikir kreatif & Memiliki acuan tujuan positif \\
\hline Intra-personal & Kemampuan memotivasi \\
& Kemampuan memimpin \\
& Kemampuan negosiasi \\
& Kemampuan presentasi \\
Kemampuan komunikasi & Kemampuan membuat relasi \\
& Kemampuan bicara di muka umum \\
\hline $\begin{array}{l}\text { Gabungan antara } \\
\text { Personal dan Intra- } \\
\text { personal }\end{array}$ & $\begin{array}{l}\text { Kejujuran, } \\
\text { Berlakung adil, } \\
\text { Kemampuan bekerja sama, } \\
\text { Kemampuan beradaptasi, } \\
\text { Kemampuan berkomunikasi, } \\
\text { Toleran, } \\
\text { Hormat terhadap sesama, } \\
\text { Kemampuan mengambil keputusan, } \\
\text { dan Kemampuan memecahkan masalah }\end{array}$ \\
\hline
\end{tabular}


Berdasarkan definisi di atas diperoleh tiga catatan penting. Pertama, bahwa pada dasarnya soft skills merupakan kemampuan yang sudah melekat pada diri seseorang, tetapi dapat dikembangkan dengan maksimal dan dibutuhkan dalam dunia pekerjaan sebagai pelengkap dari kemampuan hard skills. Kedua, soft skills dibedakan menjadi dua macam, yaitu: soft skills yang terkait dengan personal dan soft skills yang terakait dengan intra personal. Contoh soft skills personal adalah kemampuan mengendalikan emosi dalam diri, dapat menerima nasehat orang lain, mampu memanajemen waktu, dan selalu berpikir positif. Sementara itu, contoh soft skills intra personal adalah kemampuan berhubungan atau berinteraksi dengan orang lain, bekerja sama dengan kelompok lain, dan lain lain. Ketiga, bahwa soft skills merupakan komplemen dari hard skills. Jika hard skills berkaitan dengan IQ, otak kiri serta kemampuan teknis dan akademis seseorang yang diperlukan dalam dunia kerja; maka soft skills berkaitan dengan EQ, otak kanan serta kemampuan non-teknis dan non-akademis seseorang yang diperlukan dalam kehidupan sehari-hari.

\section{Pengembangan Soft Skills Mahasiswa}

Pengembangan menurut Kamus Besar Bahasa Indonesia diartikan perbuatan. Sebagai proses, cara atau perbuatan mengembangkan. Jadi yang dimaksud dengan pengembangan di sini adalah cara mengembangkan atau menjadikan suatu lebih baik dan sempurna.

Menurut Muqowim sebagaimana dikutip oleh Irawati mendefinisikan bahwa soft skills sebagai perilaku personal dan interpersonal yang mengembangkan dan memaksimalkan kinerja manusia seperti membangun tim, perbuatan keputusan, inisiatif, dan komunikasi.

Sedangkan menurut Illah Sailah dikutip oleh Irawati, bahwa Soft skills merupakan keterampilan seseorang dalam berhubungan dengan orang lain (termasuk dengan dirinya sendiri). Atribut soft skills, dengan demikian meliputi nilai yang dianut, motivasi, perilaku, kebiasaan, karakter dan sikap. Atribut soft skills ini dimiliki oleh setiap orang dengan kadar yang berbeda-beda, dipengaruhi oleh kebiasaan berfikir, berkata, bertindak dan bersikap. Namun, atribut ini dapat berubah jika yang bersangkutan mau merubahnya dengan cara berlatih membiasakan diri dengan hal-hal yang baru.

Sebelum membahas tentang soft skills terlebih dahulu membahas tentang life skills atau kecakapan hidup. Istilah hidup, tidak sematamata memiliki kemampuan tertentu saja (vocational job), namun harus 
memiliki kemampuan dasar pendukungnya secara fungsional seperti membaca, menulis, menghitung, merumuskan, dan memecahkan masalah, mengolah sumber daya, bekerja dalam tim, terus belajar di tempat kerja, mempergunakan teknologi. Program pendidikan life skillsadalah pendidikan yang dapat memberikan bekal keterampilan yang praktis, terpakai, terkait dengan kebutuhan pasar kerja, peluang usaha dan potensi ekonomi atau industri yang ada di masyarakat. Life skills ini memiliki cakupan yang luas, berinteraksi antara pengetahuan yang diyakini sebagai unsur penting untuk hidup lebih mandiri (Abdullah Aly: 2017)

Departemen pendidikan nasional membagi life skills (kecakapan hidup) menjadi empat jenis, yaitu:

1. Kecakapan personal yang mencakup kecakapan mengenal diri dan kecakapan berfikir rasional.

2. Kecakapan sosial.

3. Kecakapan akademik.

4. Kecakapan vokasional.

Menurut Nasaruddin Salam, sejauh ini dalam upaya pengembangan soft skill, pada kurikulum dimana saja di perguruan tinggi presentase dari soft skill hanya berkisar sepuluh persen. Sisanya adalah hard skillyakni ada 90 persen ini berdasarkan sistem pendidikan di Indonesia. Hal ini bertolak belakang dengan yang seharusnya terjadi bahwa berdasarkan data yang ada soft skill yang harus dimiliki seseorang sangat berpengaruh sebanyak 80 persen, dan kemampuan teknis atau hard skill hanya 20 persen. Ini berarti kontribusi soft skillyang dibutuhkan pada dunia kerja cukup tinggi, sehingga dibutuhkan SDM/mahasiswa yang memiliki karakter (soft skills) kuat (Sri Palupi).

Soft skills merupakan kompetensi bersifat non teknis yang menunjuk pada karakteristik kepribadian, nampak pada perilaku seseorang baik saat berinteraksi dalam situasi sosial, kemampuan berbahasa, kebiasaan diri, ataupun sifat-sifat penting untuk mendukung perilaku optimis. Soft skills sebagai kemampuan seseorang untuk memotivasi dirinya, menggunakan inisiatifnya, mempunyai pemahaman tentang apa yang dibutuhkan untuk dilakukan dan dapat dilakukan dengan baik, berguna mengatasi persoalan kecil yang muncul secara tiba-tiba dan terus dapat bertahan bila problem tersebut belum terselesaikan. Soft skills terbagi menjadi dua kategori yaitu soft skills inter-personal dan intra-personal. Kategori intrapersonal merupakan aspek-aspek skills yang menjelaskan tentang kemampuan untuk mengelola diri sendiri manakala yang bersangkutan berada pada situasi kerja. Kategori interpersonal merupakan aspek skills 
yang menjelaskan kemampuan untuk mengelola lingkungan kerja sehingga dirinya mampu beradaptasi dengan situasi kerja.

Keterampilan yang dimasukkan dalam kategori soft skills antara lain integritas, kedisiplinan, jujur, inisiatif, motivasi, etika, kerja sama dalam tim, kepemimpinan, kemauan belajar, komitmen, mendengarkan, tangguh, fleksibel, komunikasi lisan, dan berargumentasi logis.

Persiapan sumber daya manusia (lulusan) tidak hanya dari segi kuantitas saja tetapi juga dari segi kualitas antara lain dengan memiliki/ mempunyai soft skills yang baik sehingga sumber daya manusia yang siap pakai dan dapat bersaing dengan tenaga-tenaga ahli dari manca negara (sumber daya manusia yang komparatif dan kompetitif. Tanggung jawab menurut Barbara A. Lewis adalah :

sikap dapat diandalkan, ketekunan, terorganisasikan, tepat waktu, menghormati komitmen, perencanaan"(Sri Palupi).

Sebagaimana yang Imam Al-Ghazali katakan, "Manusia seluruhnya akan hancur, kecuali orang-orang yang berilmu. Semua orang yang berilmu akan hancur, kecualiorang-orang yang beramal. Semua orang yang beramal pun akan hancur, kecuali orang-orang yang ikhlas dan jujur" (Marzuki).

\section{Upaya Pengembangan Soft Skills}

Pengembangan soft skils dapat dilakukan melalui proses pembelajaran (intrakurikuler) dan kegiatan kemahasiswaan (ekstrakurikuler). Pengembangan soft skils melalui kegiatan belajar atau tatap muka di dalam kelas memerlukan kreativitas dosen pengampu mata kuliah dengan tetap pada pencapaian kompetensi mata kuliah tersebut. Pengembangan soft skils melalui kurikulum dapat ditempuh dengan dua cara. Pertama, melalui kegiatan pembelajaran yang secara eksplisit diintegrasikan dalam mata kuliah yang dituangkan dalam Silabus, SAP (Satuan Acara Perkuliahan) atau RPP (Rencana Pelaksanaan Pembelajaran). Kedua, dapat dilakukan melalui proses hidden curriculum, yaitu suatu strategi pengembangan soft skils yang disampaikan oleh dosen kepada mahasiswa secara terintegrasi pada saat perkuliahan berlangsung. Biasanya cara kedua ini dilakukan dosen melalui panutan (contoh atau teladan), dan juga melalui pesanpesan selingan pada saat pelaksanaan perkuliahan. Upaya pengembangan soft skils melalui pesan-pesan selingan dapat menggunakan kata-kata mutiara, lagu-lagu, peribahasa, cerita, film (video clip), yang memotivasi 
dan inspiratif, dan tidak kalah penting adalah peran pimpinan (dosen) sebagai role model (Ni Kadek Sinarwati: 2014).

Endrotomo menyatakan apa yang dilakukan dosen, mahasiswa dan kemampuan yang bisa diperoleh mahasiswa dari model pembelajaran kooperatifadalah:yangdilakukan mahasiswa membahas dan menyimpulkan masalah/tugas (materi) yang diberikan dosen secara berkelompok, yang dilakukan dosen merancang dan memonitor proses belajar dan hasil belajar, menyiapkan suatu masalah/kasus/latihan soal atau bentuk tugas yang diselesaikan mahasiswa secara berkelompok. Adapun kemampuan (soft skills) yang bisa diperoleh mahasiswa adalah team work, toleransi, kepemimpinan, percaya diri, komunikasi dan percaya diri.

Maka muncul suatu pertanyaan, yaitu: Apakah mahasiswa sudah punya soft skills? Setiap orang sudah dianugerahkan berbagai soft skills. Tetapi, tidak semua dapat mengasah, mengembangkan dan memanfaatkannya. Banyak diantara kita tidak menyadari bahwa soft skills dapat membawa menuju kesuksesan, termasuk sukses dalam pembelajaran. Bahkan belakangan ini ada suatu gejala mendewakan uang. Semuanya bisa diraih dengan uang, termasuk nilai bagus, pekerjaan bagus, atau jabatan yang bagus. Gejala ini mengecilkan peran soft skills.

Dikutip dari tulisan Illah Sailah, Penelitian mengenai soft skills telah banya dilakukan, Mitsubishi Research Institute (dalam Endrotomo, 2010) menyatakan faktor yang memberi kontribusi keberhasilan dalam dunia kerja adalah fiansial 10\%, keahlian bidangnya 20\%, net working 30\% dan soft skills 40\%. Selain itu hasil penelitian NACE (National Asssociation of Colleges and Employers) pada tahun 2005 yang menyebutkan bahwa umumnya pengguna tenaga kerja membutuhkan keahlian kerja berupa 80\% soft skills dan 20 hard skills (Ni Kadek Sinarwati: 2014).

Dalam pengembangannya, ada beberapa Metode yang digunakan dalam Pengembangan Soft Skills :

1. Pengarahan

Dalam proses pengembangan soft skills mahasiswa dengan pemberian pengarahan sebelum melaksanakan berbagai kegiatan, hal itu mutlak dan sangat penting untuk dilaksanakan. Dengan pengarahan, mahasiswa akan diberikan pemahaman terhadap seluruh kegiatan yang akan dilaksanakan dan dievaluasi setelahnya untuk mengetahui standar pelaksanaan kegiatan tersebut. Pemahaman ini sangatlah diperlukan agar mereka mengerti untuk apa melaksanakan kegiatan, bagaimana teknik pelaksanaan, mengapa dan bagaimana pelaksanaan, apa isi dan filosofinya. 


\section{Pelatihan}

Seperti disebutkan diatas, bahwa pengarahan saja tidak cukup, mahasiswa harus mendapatkan pelatihan-pelatihan hidup sehingga mereka bisa tampil dalam bersikap dan menyikapi kehidupan ini, memiliki wawasan yang luas, baik wawasan keilmuan, pemikiran dan pengalaman.

3. Penugasan

Penugasan adalah proses penguatan dan pengembangan diri untuk berperan dan mengfungsikan dirinya dalam berbagai kegiatan dan tugas, maka dialah yang akan kuat dan terampil dalam menyelesaikan berbagai problem hidup. Siapa yang banyak mengambil inisiatif, mencari pekerjaan atau tugas-tugas, dialah yang akan banyak mendapatkan keuntungan.

4. Pembiasaan

Dalam proses pendidikan dan pengembangan soft skills mahasiwa belumlah cukup hanya dengan pengarahan, pelatihan dan penugasan. Maka pembiasaan merupakan unsur penting dalam pengembangan mental dan karakter mahasiswa.

5. Pengawalan

Yang dimaksud dengan pengawalan adalah seluruh tugas dan kegiatan mahasiswa selalu mendapatkan bimbingan dan pendampingan, sehingga seluruh apa yang telah diprogramkan mendapatkan contoh, evaluasi, dan langsung bisa diketahui. Pengawalan ini sangat penting untuk mendidik dan memotivasi, tidak saja bagi mahasiswa, tetapi bagi pengurus, instruktur bahkan kyai juga ikut terdidik.

6. Uswah Hasanah

Uswah hasanah adalah upaya memberikan dan menjadi contoh yang baik bagi orang lain. Dalam kaitan pendidikan, upaya ini menjadi sangat penting dalam keberhasilan pendidikan. Rasullulah Muhammad SAW. beserta para sahabatnya berhasil membina umat, karena kemampuannya menjadi suri tauladan bagi umatnya.

7. Pendekatan

Ketujuh metode tersebut belum mencukupi bila tidak disertai dengan pendekatan-pendekatan. Ada tiga macam pendekatan, yaitu:

a. Pendekatan Manusiawi

Yaitu pendekatan secara fisik dengan cara memanusiakan mahasiswa, bahwa mahasiswa adalah calon pemimpin yang harus disikapi dan dipersiapkan untuk menjadi pemimpin. Mengapa harus dekat secara fisik, hal ini menjadi sangat penting, karena proses 
pemahasiswaan bisa dilakukan apabila secara fisik dekat. Bagaimana akan bisa diketahui pola, sikap dan perilaku mahasiswa, bila tidak bersentuhan langsung, dengan sentuhan langsung, seseorang bisa dinilai, diarahkan dan dievaluasi.

b. Pendekatan Program

Pendekatan secara fisik saja terhadap mahasiswa tidaklah mencukupi, maka harus dengan pendekatan program atau tugas. Bagaimanapun hebatnya pendekatan manusiawi dengan segala kebaikan hati belumlah cukup. Maka pendektan tugas atau program justru akan menjadikan mahasiswa menjadi lebih terampil, bertambah pengalaman dan wawasan. Dia akan berhati-hati dan menumbuhkan jiwa kesungguhan dan militansi. Karena penugasan berarti mendidik untuk bertanggung jawab dan bisa dipertanggungjawabkan.

c. Pendekatan Idealisme

Dua pendekatan diatas, dalam proses pelaksanaan metode pengembangan soft skills mahasiswa belumlah cukup, karena kedua pendekatan ini seringkali hanya bersifat pragmatis, belum menyentuh tataran isi dan nilai, filsafat dan ruh kegiatan yang diberikan. Maka harus ada pendekatan idealisme. Pendekatan ini lebih merupakan upaya memberikan ruh, ajaran filosofis dibalik penugasan (Damanhuri: 2016).

\section{Relevansi Soft Skills terhadap Akhlak Mahasiswa}

Akhlak adalah suatu keadaan yang melekat pada jiwa manusia, yang daripadanya lahir perbuatan-perbuatan dengan mudah, tanpa melalui proses pemikiran, pertimbangan atau penelitian. Jika keadaan (hak) itu melahirkan perbuatan yang baik dan terpuji menurut pandangan akal dan syarak (hukum islam), keadaan tersebut disebut akhlak yang baik, sedangkan jika perbuatan-perbuatan yang timbul itu tidak baik, dinamakan akhlak yang buruk. Kata akhlak merupakan bentuk jamak dari kata alkhuluq atau al-khulq, yang secara etimologis berarti (1) "tabiat, budi pekerti “, (2) "kebiasaan atau adat", (3) "keperwiraan, kesatriaan, kejantanan”, (4) "agama”, dan (5) "kemarahan (al-ghadhab)".

Karena akhlak merupakan suatu keadaan yang melekat di dalam jiwa, maka suatu perbuatan baru disebut akhlak kalau terpenuhi beberapa syarat.

1. Perbuatan itu dilakukan berulang-ulang. Kalau suatu perbuatan itu hanya dilakukan sesekali saja, maka tidak dapat disebut akhlak. 
Misalnya, pada suatu saat, orang yang jarang berderma tiba-tiba memberikan uang kepada orang lain karena alasan tertentu. Dengan tindakan ini ia tidak dapat disebut murah hati atau berakhlak dermawan karena hal itu tidak melekat dalam jiwanya.

2. Perbuatan itu timbul dengan mudah tanpa dipikirkan atau diteliti lebih dulu sehingga ia benar-benar merupakan suatu kebiasaan. Jika perbuatan itu timbul karena terpaksa atau setelah dipikirkan dan dipertimbangkan secara matang, tidak disebut akhlak.

Akhlak menempati posisi yang sangat penting dalam islam sehingga setiap aspek dari ajaran agama ini selalu berorintasi pada pembentukan dan pembinaan akhlak yang mulia, yang disebut al-akhlak al-karimah, hal ini tercantum antara lain dalam sabda rasulullah saw (Ahmad Taufik dan Muhammad Rohmadi: 2010).

Mukmin yang paling sempurna imannya adalah orang yang paling baik akhlaknya. (HR Tirmizi).

Dalam membentuk akhlak mahasiswa, selain menyajikan proses pembelajaran, Perguruan Tinggi juga mewadahi berbagai kegiatan kemahasiswaan yang berguna untuk menggali potensi mahasiswa sehingga soft skill dan akhlak mahasiswa dapat terbentuk. Berdasarkan tujuan pendidikan harus mencakup ketiga aspek pendidkan, yaitu aspek kognitif, aspek afektif, dan aspek psikomotorik. Kenyataannya di lapangan masih mendominasi pencapaian dalam bentuk kognitif. Padahal di dalam kurikulum tertulis tujuan pendidikan harus mencapai ketiga aspek pendidikan tersebut. Hal ini, menunjukkan ekspektasi berbanding dengan kenyataan.

Apabila ketiga aspek pendidikan tidak seimbang atau hanya mendominasi salah satunya maka dalam implementasinya di kehidupan tidak akan sempurna. Sehingga sangat perlu mengembangkan soft skills sebagai upaya pencapaian aspek psikomotorik dan pembentukan akhlah untuk mencapai aspek afektif.

Akhlak dan soft skills bagaikan dua sisi mata uang, yang tak dapat dipisahkan dalam implementasinya di kehidupan sehari-hari. Dan ini merupakan realisasi dari sabda Rasulullah: (Abuddin Nata: 2009)

$$
\text { إنَّمَا بُحِثْتُ لِالِتَمََمَ مَكَرِمَ الْاَخْلَقِق }
$$

bahwasanya aku diutus Allah untuk menyempurnakan keluhuran budi pekerti".

Berdasarkan teori menurut Nasaruddin Salam, presentase dari soft skill di perguruan tinggi hanya berkisar sepuluh persen. Sisanya adalah 
hard skill yakni ada 90 persen ini berdasarkan sistem pendidikan di Indonesia. Hal ini bertolak belakang dengan yang seharusnya terjadi bahwa berdasarkan data yang ada soft skill yang harus dimiliki seseorang sangat berpengaruh sebanyak 80 persen, dan kemampuan teknis atau hard skill hanya 20 persen. Ini berarti kontribusi soft skill yang dibutuhkan pada dunia kerja cukup tinggi, sehingga dibutuhkan SDM/mahasiswa yang memiliki karakter(soft skills) kuat (Sri Palupi).

Dalam hal ini, nilai IPK bukanlah satu-satunya faktor penentu keberhasilan seseorang. Karena faktor penentu keberhasilan seseorang bisa juga didominasi oleh kemampuan soft skills yang dimiliki oleh oang tersebut.

Diantara kemampuan soft skills sebagai berikut:

1. Kejujuran. Dalam kehidupan baik dunia pendidikan maupun dunia kerja, kemampuan ini sangatlah memberikan nilai lebih pada kualifikasi seseorang. Bahkan kemampuan ini juga dimiliki oleh Rasulullah dan dianjurkan kepada manusia. Apalagi sekarang semakin sulit menemukan orang yang benar-benar jujur, dibuktikan dengan nihilnya ketuntasan kasus korupsi dan juga maraknya mall praktik dalam dunia pendidika seperti kecurangan-kecuangan dalam pelaksanaan Ujian Nasional (UN).

2. Disiplin. Setiap instansi atau lembaga biasanya menjadikan kemampuan ini sebagai salah satu persyaratannya. Mengingat masyarakat Indonesia masih banyak yang tidak tepat waktu atau tidak disiplin dalam sebuah pertemuan, acara, dan sebagainya. Sebagaimana kiasan "waktu adalah emas, waktu adalah pedang, waktu adalah ibadah". bahkan Rasulullah mengajarkan kita untuk tepat waktu dalam menjalankan segala bentuk perintahnya seperti, sholat. Dalam hal ini, sepantasnya kita menerapkan sikap disiplin dalam kehidupan.

3. Mudah bergaul. Dengan kemampuan ini banyak manfaat yang didapatkan, diantara memperluas networking, memudahkan dalam segala urusan, komunikasi lancar dan sebagainya. Bahkan Rasulullah sangat mudah bergaul dengan siapa saja sekalipun dengan orang orang yang tidak menyukainya.

4. Motivasi. Sebagaimana diketahui ada dua faktor munculnya semangat seseorang, yaitu faktor intinsik dan faktor ekstrinsik. Meskipun faktor intinsik lebih kuat, namun faktor ekstrensik juga dipelukan. Rasulullah pun selama hidupnya disekelilingi dengan orang-orang yang mendukung beliau dalam melaksanakan dakwah dijalan Allah.

5. Kerja keras. Sering kita dengar kunci untuk mencapai kesuksesan adalah kerja keras. Kemampuan ini salah satu soft skills harus 
diterapkan dalam segala bidang kehidupan. Rasulullah pun bekerja keras berdakwah dijalan Allah untuk umatnya tercinta. Kenyataannya kemampuan ini sering terkendala rasa malas, sehingga tidak banyak yang dapat mencapai kesuksesan dalam hidupnya.

6. Kecintaan pada yang dikerjakan. Bukankah menggeluti suatu pekerjaan yang tidak disukai akan menimbulkan rasa tertekan dan kebosanan.

7. Kepemimpinan. Kemampuan ini diperlukan dalam segala bidang kehidupan baik dalam mengarungi rumah tangga, pekerjaan, organisasi dan sebagainya. Rasulullah sosok teladan kepemimpinan adil, sepatutnya seorang pemimpin meneladani sikap beliau.

Berdasarkan kemampuan soft skills di atas, sudah seharusnya dimiliki dan dikembangkan oleh mahasiswa. Hampir semua soft skills ini tidak terjangkau dengan IPK. Biasanya diperoleh dari kegiatan kemahasiswaan dan proses pembelajaran yang tepat.

Nabi Muhammad Saw. bersabda dalam salah satu hadis yang berbunyi:

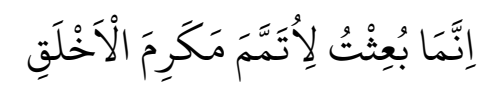

Sesungguhnya aku diutus hanyalah untuk menyempurnakan akhlak mulia

Hadis ini mengisyaratkan bahwa kehadiran Nabi Saw. di muka bumi ini membawa misi pokok untuk menyempurnakan akhlak manusia yang mulia. Dengan pembentukan akhlak yang baik diharapkan dapat mengimplementasikan uswatun hasanah di dalam kehidupan sehari-hari atau bermasyarakat.

Apabilatujuan pendidikanmencakupranahaspekkognitif, psikomotorik dan afektif secara seimbang maka dalam penerapannya di kehidupan dapat sempurna. Sehingga Perguruan tinggi dapat menghasilkan output yang tidak hanya memiliki intelektual tinggi namun juga kemampuan mumpuni serta akhlak baik (uswatun hasanah) untuk dimanfaatkan pada lingkungan sekitar.

\section{Simpulan}

Berdasarkan pendapat Ilah sailah, Soft skills adalah keterampilan atau kemampuan seseorang dalam berhubungan dengan orang lain (interpersonal skills) dan keterampilan dalam mengatur dirinya sendiri (intrapersonal skills) yang mampu mengembangkan secara maksimal unjuk kerja (performans) seseorang". 
Dalam hal ini, upaya untuk mengembangkan soft skills terdapat beberapa cara diantaranya dalam proses pembelajaran dan kegiatan kemahasiswaan. Dengan memanfaatkan upaya pengembangan tersebut, diharapkan mahasiswa nantinya dapat mencakup tujuan pendidikan pada ranah aspek kognitif, aspek psikomotorik dan aspek afektif. Sehingga perguruan tinggi akan melahirkan output yang berintelektual tinggi, berkemampuan mumpuni dan berakhlakul karimah (uswatun hasanah).

Relevansi soft skills terhadap akhlak mahasiswa, bagaikan dua elemen magnet yang tidak dapat dipisahkan atau saling berkaitan. Rasulullah mengajarkan kepada manusia untuk berakhlak terpuji. Karena tidak ada gunanya jika hanya mempunyai banyak kemampuan tetapi akhlaknya tercela. Sehingga mahasiswa harus menyeimbangkan kemampuan soft skills dan akhlak terpuji dalam mengimplementasikan pada kehidupan.

\section{DAFTAR PUSTAKA}

Aly. A, Pengembangan Pembelajaran Karakter Berbasis Soft Skills Di Perguruan Tinggi, Ishraqi, Hasil Penelitian (Online), Volume 1 No. 1 Januari 2017.

Amin. A. R, Penelitian Kepustakaan (Library Research), Website Banjirembun.Com, Https://Www.Banjirembun.Com/2012/04/ Penelitian-Kepustakaan.Html?M=1.

Damanhuri, Metode Pengembangan Soft Skills Mahasiswa Universitas Darussalam (Unida) Pondok Modern Gontor Di Mantingan Ngawi Jawa Timur Indonesia Angkatan 2015/2016, Tesis (Online), Universitas Muhammadiyah Surakarta, 2016.

Marzuki, Pembentukan Kultur Akhlak Mulia Di Kalangan Mahasiswa Uny Melalui Pembelajaran Pai, Hasil Penelitian (Online).

Nata. A, Akhlak Tasawuf, Jakarta : Pt Raja Grafindo Persada, 2009.

Palupi. S, Upaya Membangun Karakter (Soft Skills) Mahasiswa Bidang Boga, Hasil Penelitian (Online).

Sinarwati. N. K, Apakah Pembelajaran Kooperatif Tipe Stad Mampu Meningkatkan Soft Skills Dan Hard Skills Mahasiswa?, Jurnal Ilmiah 
Akuntansi Dan Humanika, Singaraja, Jinah, Volume 3 No. 2 Juni 2014.

Tani. F, Penelitian Kualitatif: Empat Tipe Triangulasi Dalam Pengumpulan Data, Kompasiana, Https://Www.Kompasiana.Com/Mtf3lix5tr/553 5a2946ea8347510da42d9. Selasa/Penelitian-Kualitatif-024-EmpatTipe-Triangulasi-Dalam-Pengumpulan-Data

Taufik. A Dan Rohmadi. M, Pendidikan Agama Islam : Pendidikan Karakter Berbasis Agama, Surakarta : Yuma Pustaka, 2010, Cetakan Ke-1. 